Original Research Article

\title{
Relaxant effects of aqueous cold extracts of Carum copticum on smooth muscle
}

\author{
G. Megha Vani ${ }^{1}$, P. Ramesh ${ }^{2}$, M. Radhika ${ }^{3}$, G. Devashankaraiah ${ }^{2 *}$, P. S. R. K. Haranath ${ }^{4}$
}

${ }^{1}$ Department of Pharmacology, Kamineni Academy of Medical Sciences and Research Centre, LB Nagar, Hyderabad,

Telangana, India

${ }^{2}$ Department of Pharmacology, SVS Medical College, Mahabubnagar, Telangana, India

${ }^{3}$ Department of Ophthalmology, ESIC Medical College, Sanath Nagar, Hyderabad, Telangana, India

${ }^{4}$ Department of Pharmacology, Kurnool Medical College, Kurnool, Andhra Pradesh, India

Received: 12 April 2017

Revised: 24 May 2017

Accepted: 30 May 2017

*Correspondence to:

Dr. G. Devashankaraiah, Email: pharmacology.svsmc@ gmail.com

Copyright: (C) the author(s), publisher and licensee Medip Academy. This is an openaccess article distributed under the terms of the Creative Commons Attribution NonCommercial License, which permits unrestricted noncommercial use, distribution, and reproduction in any medium, provided the original work is properly cited.

\begin{abstract}
Background: The objective was to study the nature of relaxant effect of cold aqueous extracts of Carum copticum on rat alimentary tract and uterus.

Methods: The aqueous cold extracts of Carum copticum (omum) whole seeds $\left(\mathrm{OE}_{1}\right)$ or ground seeds $\left(\mathrm{OE}_{2}\right)$ was prepared by leaving them $(10 \mathrm{~g}$ to $100 \mathrm{~mL})$ in distilled water for 4 hrs. Rat isolated tissues like stomach, duodenum, jejunum or uterus $4 \mathrm{~cm}$ pieces were mounted in a $20 \mathrm{~mL}$ bath containing Tyrode solution or De Jalons at $37^{\circ} \mathrm{C}$ with continuous aeration. The effect of Carum copticum extracts and thymol on spontaneous activity of intestine and on acetylcholine $(\mathrm{ACh})$, Histamine $(\mathrm{H})$, Barium chloride $\left(\mathrm{BaCl}_{2}\right)$ induced contractions or Adrenaline produced (Adr) relaxations were observed. Thymol content of omum was estimated by HPLC.

Results: Omum extracts decreased or abolished spontaneous contractions of intestine but did not antagonize the contractions induced by $\mathrm{ACh}, \mathrm{H}$ or relaxation induced by adrenaline. Thymol did not show any such effect. The stimulant action of $\mathrm{BaCl}_{2}$ was antagonized by aqueous cold extracts of omum similar to Papaverine.

Conclusions: The relaxant effect of Carum copticum on rat intestine appears to be a direct effect on smooth muscle like papaverine.
\end{abstract}

Keywords: Carum copticum, Papaverine, Rat gut, Uterus

\section{INTRODUCTION}

Carum Copticum (Benth) f. umbellifarae is commonly known as omum, Ajwan or Bishop's weed. C. copticum fruit yields an essential oil which is composed of thymol, carvacol and other substances - $\alpha$-pinene, $\beta$-pinene $\gamma$ terpinene, p-cymene. ${ }^{1}$ A crystalline substance stearoptene is also present in it. The stearoptene is known as ajowanka-phul (crude thymol). ${ }^{2-5}$ Aqueous extracts of omum are used in household remedies for relief of gripe in children. 
The seeds are also used as spice in food. Hot aqueous extract with roasted seeds is used as a draught to control diarrhea. Traditionally Carum Copticum has several therapeutic effects including expectorant, diuretic, antiemetic, analgesic, antiasthma, anti-dyspnea, and antispasm. ${ }^{6}$ Used in the treatment of many gastrointestinal disorders such as indigestion, colic, dyspepsia and diarrhea. ${ }^{7}$ The Carum Copticum seeds have several pharmacological effects including anti-asthma and anti dyspnea analgesic. ${ }^{8,9}$ We reported earlier that aqueous extracts from roasted omum seeds contain acetylcholine (ACh) and choline. ${ }^{10}$ Presence of ACh was confirmed by its muscarinic and nicotinic actions by biological and chromatographic tests. We also observed that the cold omum extracts produce relaxation of intestine, which could account for the relief in intestinal colic. In this paper we studied the possible mechanisms of the antispasmodic effect of cold omum extracts. The seeds have an aromatic smell of thymol which is a major constituent of oil extracted from them. ${ }^{11}$ Hence we studied if thymol could be responsible for the relaxant action.

\section{METHODS}

\section{Preparation of C. copticum extracts}

Aqueous extracts were made by soaking whole seeds of omum $\left(\mathrm{OE}_{1}\right)$ or ground seeds $\left(\mathrm{OE}_{2}\right)(10 \mathrm{~g}$ to $100 \mathrm{~mL})$ in cold water for a period of 4 hours. The extract was filtered through Whatman No.1 filter paper and the filtrate used for study. The term extract used in this paper refers to the above procedure.

\section{Biological procedures}

Isolated tissues like rat stomach, duodenum, jejunum, ileum, uterus and guinea pig ileum were mounted in a $20 \mathrm{~mL}$ bath containing Tyrode/DeJalon's solution kept at $37^{\circ} \mathrm{C}$ with continuous aeration. ${ }^{12}$ The contractions/ relaxations (magnified 4 times) were recorded with an isotonic lever. The effect of omum extract and thymol on spontaneous contractions and $\mathrm{ACh}, \mathrm{H}, \mathrm{Adr}$, Oxytocin or $\mathrm{BaCl}_{2}$ induced contractions/relaxation on rat intestine/ uterus was studied. The doses added to $20 \mathrm{~mL}$ bath are given in the caption of figures. At least 6 experiments were conducted with each procedure. Representative record from one experiment is included in results.

\section{Effect on Bowel Movement}

The Wistar rats were divided into four groups of 6 rats each. Group I was control and given $1 \mathrm{~mL}$ of distilled water. The rats in other three groups i.e. II, III and IV received $1 \mathrm{~mL}, 2 \mathrm{~mL}$ and $4 \mathrm{~mL}$ of omum extract respectively daily orally for 7 days. The fecal pellets were counted daily at $10 \mathrm{a} . \mathrm{m}$. The number of pellets daily excreted by test group animals was compared with control group and statistical analysis was done by ANOVA.

\section{High performance liquid chromatography (HPLC)}

The cold aqueous extracts of whole seed $\left(\mathrm{OE}_{1}\right)$ and ground omum seeds $\left(\mathrm{OE}_{2}\right)$ were subjected to quantitative estimation of thymol content by HPLC with $\mathrm{C}_{8}$ column with acetonitrate: water $(50 ; 50 \mathrm{v} / \mathrm{v})$ as a mobile phase. The detector wave length was $275 \mathrm{~nm}$ and column oven was $40^{\circ} \mathrm{C}$. The injection volume of sample $\mathrm{OE}_{1}$ and $\mathrm{OE}_{2}$ was $5 \mu \mathrm{L}$. The thymol content was estimated.

\section{Drugs}

The following drugs were used in this study. Acetylcholine chloride (Loba Chemie Pvt. Ltd. Mumbai, India), Histamine (Himedia chemicals Ltd.), Adrenaline (S.D Fine Chemicals Ltd., Mumbai), Labetalol (Mercury laboratories Ltd, Baroda), Barium chloride (S.D. Fine chemicals Ltd., Mumbai), Atropine (Harson Labs Pvt.Ltd., Baroda), Pheniramine maleate (Sonafi India Ltd., Bangalore), Papaverine (Troikaa Pharmaceuticals Ltd.), Thymol (Johnson and George Chemicals Co. Mumbai), Oxytocin (Mercury laboratories Ltd, Baroda).

\section{RESULTS}

\section{Effect on spontaneous activity of isolated rat intestine}

The aqueous cold extract of $C$. copticum decreased or abolished spontaneous movements of rat duodenum, jejunum and ileum but fundus was stimulated. Both $\mathrm{OE}_{1}$ and $\mathrm{OE}_{2}$ produced almost equal relaxant effects. Thymol even in large dose $(1320 \mu \mathrm{M})$ did not show any such effect (Figure $1 \mathrm{a}$ and $\mathrm{b}$ ).

\section{Effect on ACh induced contraction}

The ACh induced contraction was antagonized by atropine $(2.8 \mu \mathrm{M})$ but not by omum extract $(0.4 \mathrm{~mL})$ (Figure 2).

\section{Effect on Histamine induced contraction}

Prior exposure of rat intestine to omum extract $\left(\mathrm{OE}_{1}\right.$ $0.4 \mathrm{~mL})$ did not antagonize the stimulant action of histamine (Figure 3).

\section{Relaxant effect of Omum on rat duodenum compared with adrenaline}

Adrenaline $(6 \mu \mathrm{M})$ produced relaxation of rat duodenum which was blocked by labetalol. But the relaxation produced by Omum extract $\mathrm{OE}_{1}(0.4 \mathrm{~mL})$ was not blocked by labetalol (Figure 4). 


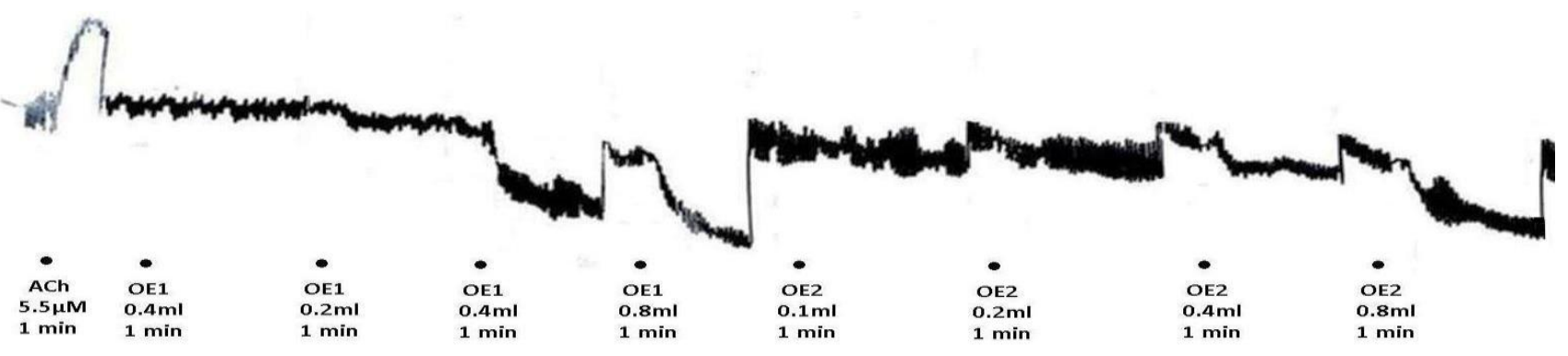

Figure 1(a): Relaxant effect of graded doses of $\mathrm{OE}_{1}$ and $\mathrm{OE}_{2}(0.1 \mathrm{~mL}$ to $0.8 \mathrm{~mL})$ on rat duodenum.

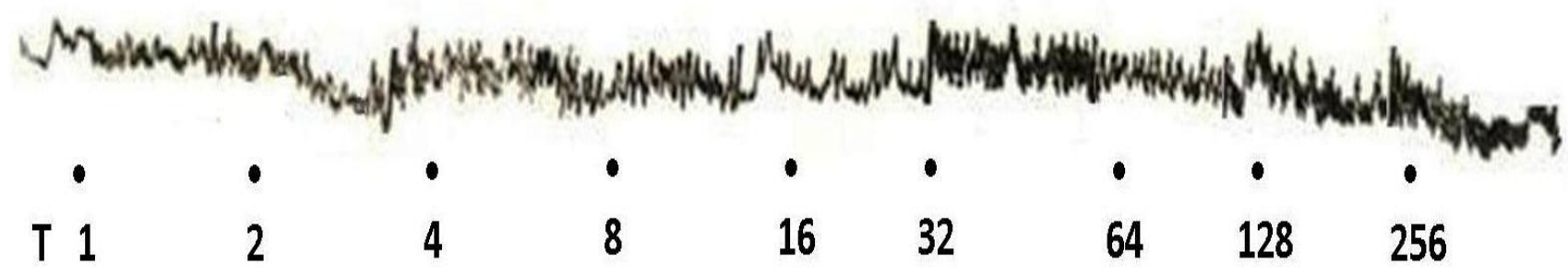

Figure 1(b): Thymol in graded doses $1(6.6 \mu \mathrm{M})$ to $256(1320 \mu \mathrm{M})$ on rat duodenum.

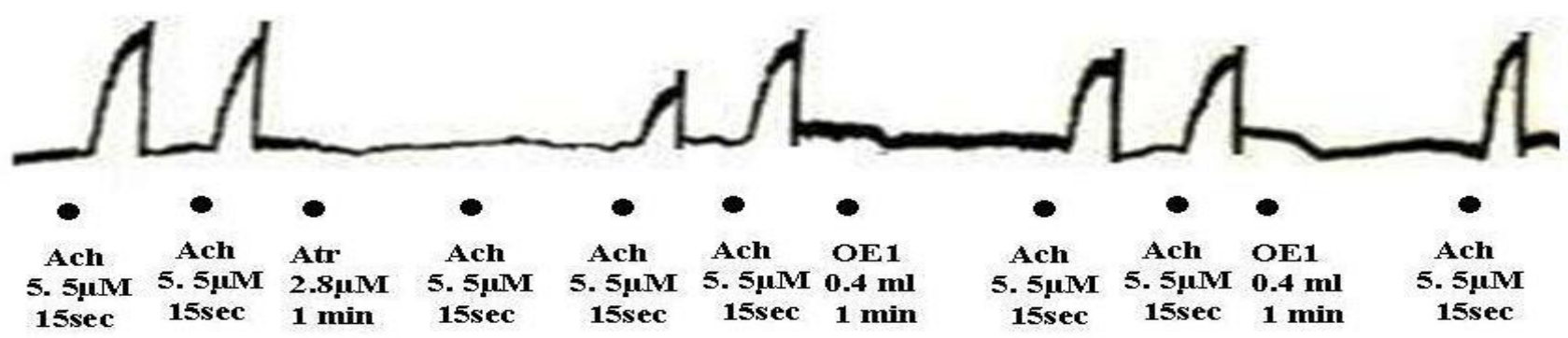

Figure 2: Record shows contractions induced by acetylcholine $(5.5 \mu \mathrm{M})$ on rat duodenum blocked by atropine $(2.8 \mu \mathrm{M})$ but not by $\mathrm{OE}_{1}(0.4 \mathrm{~mL})$.

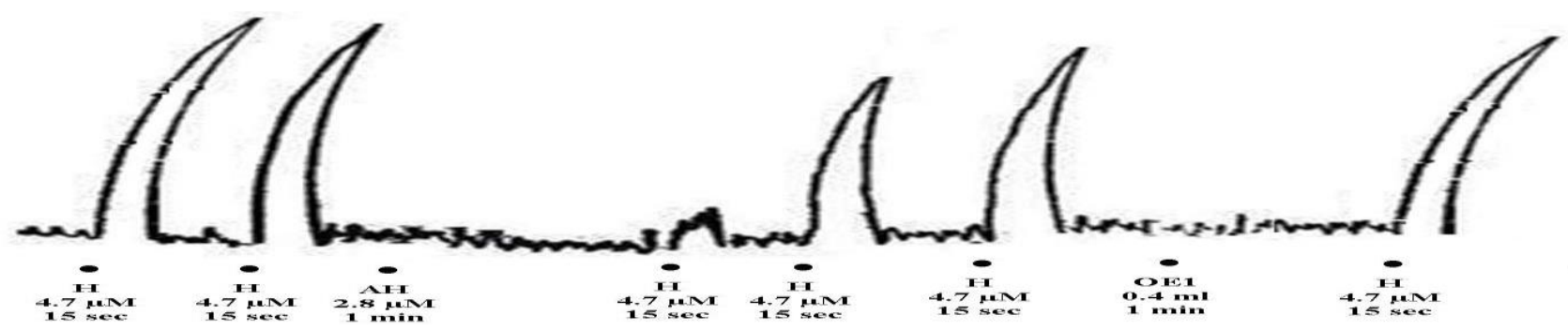

Figure 3: Record shows contractions induced by histamine $(4.7 \mu \mathrm{M})$ blocked by antihistamine (Pheniramine maleate) $(2.8 \mu \mathrm{M})$ but not by $\mathrm{OE}_{1}(0.4 \mathrm{~mL})$.

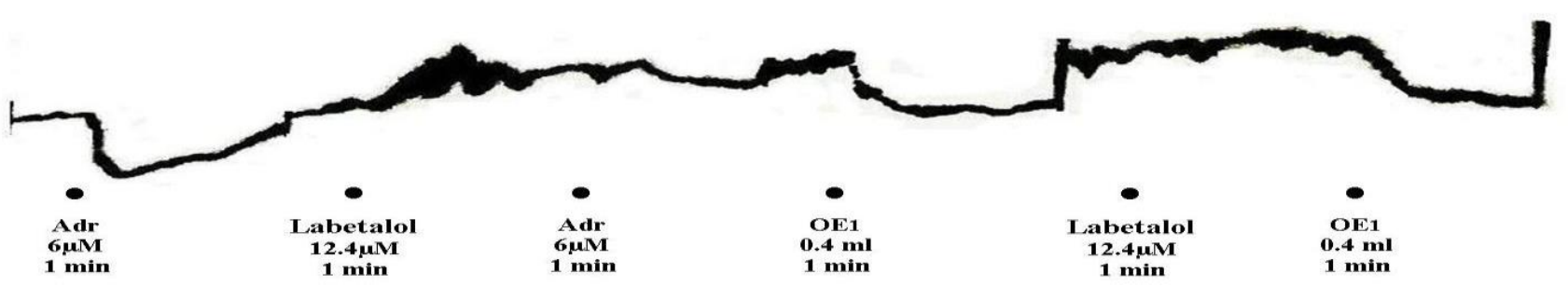

Figure 4: Record showing the blockade of adrenaline $(6 \mu \mathrm{M})$ effect by labetalol $(12.4 \mu \mathrm{M})$ but not by omum extract $\mathrm{OE}_{1}(0.4 \mathrm{~mL})$. 


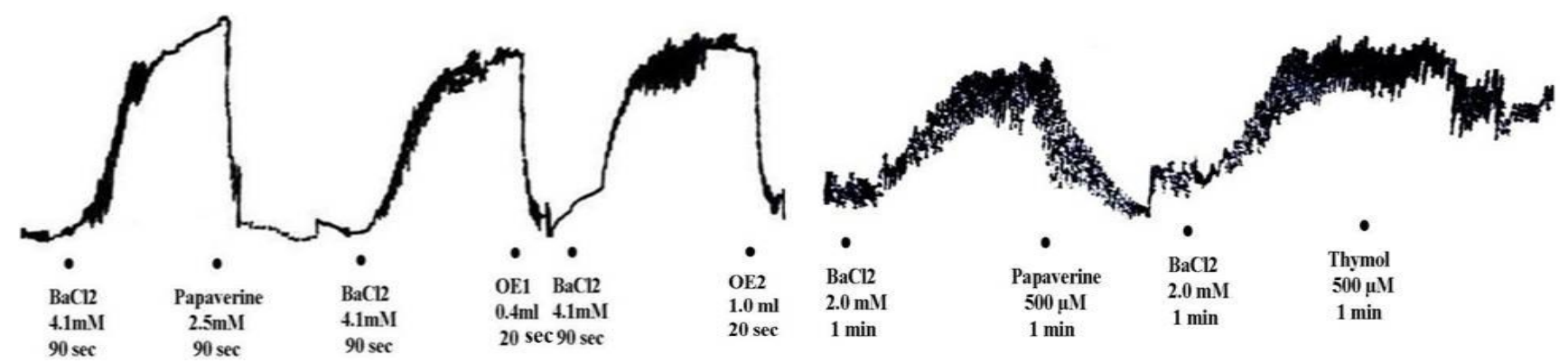

Figure 5: Tracing showing Barium chloride $(2.0 \mathrm{mM} / 4.1 \mathrm{mM})$ induced contractions on rat duodenum and its blockade by papaverine $(500 \mu \mathrm{M} / 2.5 \mathrm{mM}), \mathrm{OE}_{1}(0.4 \mathrm{~mL})$ and $\mathrm{OE}_{2}(1 \mathrm{~mL})$ but not by Thymol $(500 \mu \mathrm{M})$.

\section{Effect of Omum on Barium chloride induced contractions}

The Barium chloride $(2 \mathrm{mM} / 4.1 \mathrm{mM})$ induced contractions were antagonized by the omum extract $(0.4 \mathrm{~mL})$ on rat duodenum similar to papaverine $(500 \mu \mathrm{M} / 2.5 \mathrm{mM})$. Thymol $(500 \mu \mathrm{M})$ had no effect (Figure 5).

\section{Effect on Oxytocin induced contractions on rat uterus}

The stimulant effect of oxytocin (0.1IU) on rat uterus was blocked by adrenaline $(6 \mu \mathrm{M})$ but not by $\mathrm{OE}_{1}(0.4 \mathrm{~mL})$.

\section{Effect on Bowel movement}

The omum extract decreased the number of pellets daily excreted by the rats in test groups when compared to control group. It was highly significant in $1^{\text {st }}$ test group $(\mathrm{P}=0.0004)$ (Table 1 and 2).

Table 1: The average pellets excreted per day by control, test 1, 2 and 3 groups of rats.

\begin{tabular}{|lllllll|}
\hline $\begin{array}{l}\text { Para- } \\
\text { meters }\end{array}$ & N & $\begin{array}{l}\text { Mini- } \\
\text { mum }\end{array}$ & $\begin{array}{l}\text { Maxi- } \\
\text { mum }\end{array}$ & Mean & SD & $\begin{array}{l}\text { P- } \\
\text { value }\end{array}$ \\
\hline Control & 7 & 186 & 213 & 195.7 & 10.6 & \\
\hline Test 1 & 7 & 129 & 175 & 158.4 & 17.1 & \multirow{2}{*}{0.004} \\
\cline { 1 - 5 } Test 2 & 7 & 170 & 238 & 201.4 & 25.4 & \\
\cline { 1 - 5 } Test 3 & 7 & 164 & 234 & 190.7 & 27.2 & \\
\hline
\end{tabular}

Table 2: Comparison between control vs. test 1, test 2 and test 3 for the parameter pellet count.

\begin{tabular}{|llll|}
\hline Parameters & $\begin{array}{l}\text { Mean } \\
\text { difference }\end{array}$ & P-value & P-value \\
\hline $\begin{array}{l}\text { Control vs. } \\
\text { test 1 }\end{array}$ & 37.3 & 0.0004 & Significant \\
\hline $\begin{array}{l}\text { Control vs. } \\
\text { test 2 }\end{array}$ & 5.7 & 0.593 & NS \\
\hline $\begin{array}{l}\text { Control vs. } \\
\text { test 3 }\end{array}$ & 5.0 & 0.659 & NS \\
\hline
\end{tabular}

\section{Thymol content and its effect on rat gut and uterus}

The Thymol content estimated by HPLC in the aqueous extract of whole seeds $\left(\mathrm{OE}_{1}\right)$ was $0.066 \mu \mathrm{g} / \mathrm{mL}$ and in ground seed extract $\left(\mathrm{OE}_{2}\right)$ is $34.88 \mu \mathrm{g} / \mathrm{mL}$. The spontaneous contractions of rat intestine/uterus and the stimulant effect of $\mathrm{ACh}, \mathrm{H}$, Oxytocin or $\mathrm{BaCl}_{2} /$ relaxant effect of adrenaline were not influenced by Thymol.

\section{DISCUSSION}

Omum has been used in various conditions as carminative, expectorant, antimicrobial, treatment of common cold and acute pharyngitis etc. as reviewed. ${ }^{13}$ In this review it is reported to have anticholinergic, $\mathrm{H}_{1}$ antagonism and stimulation of adrenergic receptors in guinea pig tracheal chain to account for its use in bronchial Asthma. Most of these studies are with chemical extracts of its components.

Our interest was in its domestic use as aqueous solutions. We found that aqueous extracts with roasted seeds had large amounts of acetylcholine and choline to explain its stimulant effect on isolated rat tissues. ${ }^{10}$ Similar presence of acetylcholine and choline in aqueous extracts is reported in aqueous extracts from roasted spices. ${ }^{14}$ Relaxation with cold omum extracts was also reported. ${ }^{10}$ The present paper investigated the possible receptor mechanisms of these relaxant effects - anti-muscarinic, antihistaminic and adrenergic systems. Even uterine contractions induced by oxytocin were not relaxed. But direct stimulant effect of Barium chloride was antagonized similar to papaverine. It was concluded that the antispasmodic effect is a direct effect on the smooth muscles. It is not due to its thymol content.

We observed constipation only with small (1mL) dose of omum extract, but not significant at higher doses of 2 or $4 \mathrm{~mL}$ ), probably because of presence of both spasmolytic and spasmogenic actions. Thus Omum contains both spasmogenic and spasmolytic components being released under different conditions. Such combinations of ingredients are known in nature as in opium from papaverum somniferum contains smooth muscle 
stimulating phenanthrene alkaloid like morphine and relaxant benzylisoquinoline alkaloid like papaverine.

The biological effects of aqueous cold extracts of Carum copticum suggest that the relaxant effect of it is most probably due to a direct action on gut smooth muscle. Further study is desirableto find out the mechanism of action.

\section{CONCLUSION}

The relaxant effect of cold aqueous extract of $C$. copticum on rat gut is direct unrelated to specific receptors.

\section{ACKNOWLEDGEMENTS}

Authors are very thankful to the Principal and Management of SVS Medical College and Palamur Biosciences Pvt. Ltd., Mahabubnagar for their help and encouragement in carrying out this research work.

\section{Funding: No funding sources}

Conflict of interest: None declared

Ethical approval: The study was approved by the Institutional Animal Ethical Committee (IAEC) and registered under Registration No.1797/PO/ERe/S/14/CPCSEA for conducting animal tissue experiment

\section{REFERENCES}

1. Chopra RN. Chopra's indigenous drugs of India. $2^{\text {nd }}$ Ed., rev. and largely rewritten / Calcutta: Academic Publishers; 1982.

2. Asghari G, Lockwood B. Metabolism of essential oil components in Carum copticum cell cultures. Rivista Italiana. EPPOS. 1996;7:676-9.

3. Farooq MO, Osman SM, Ahmad MS. The fixed oil from the seeds of carum copticum benth. (Ptychotis Ajowan). Journal of the Science of Food and Agriculture. 1953 Mar;4(3):132-4.
4. Lockwood GB, Asghari G, Hakimi B. Production of essential oil constituents by cultured cells of Carum copticum L. Flavour and fragrance journal. $2002 \mathrm{Nov}$ $1 ; 17(6): 456-8$.

5. Nadkarni KM. Indian Materia Medica, 1., $3^{\text {rd }}$ Ed. Popular Prakashan, Bombay; 1976:953-955.

6. Boskabady MH, Jandaghi P, Kiani S, Hasanzadeh L. Antitussive effect of Carum Copticum in guinea pigs. J Ethnopharmacol. 2005;97:79-82.

7. Avesina A. In: Law in Medicine. $2^{\text {nd }}$ Ed. Sharafkandi A, translator. Teheran: Soroush Press; 1985:2,187.

8. Boskababy MH, Shaikhi J. Inhibitory effect of Carum Copticum on histamine $(\mathrm{H} 1)$ receptors of isolated guinea-pig tracheal chain. $\mathrm{J}$ Ethnopharmacol 2000;69:217-27.

9. Dashti-Rahmatabadi MH, Hejazian SH, Morshedi A, Rafati A. The analgesic effect of Carum Copticum extract and morphine on phasic pain in mice. J. Ethnopharmacol. 2007;109:226-8.

10. Devasankaraiah G, Hanin I, Haranath PSRK, Ramanamurthy PSV. Cholinomimetic effect of Aqueous extracts from Carum copticum seeds. Br J Pharmac. 1974;52:613-4.

11. Bairwa R, Sodha RS, Rajawat BS. Trachyspermum ammi. Phcog Rev. 2012;6:56-60.

12. Vane JR. A sensitive method for the assay of 5hydroxytryptamine. $\mathrm{Br} \mathrm{J}$ Pharmac. Chem other. 1957;12:344-9.

13. Boskabady MH, Alitaneh S, Alavinezhad A. Carum copticum L. a herbal medicine with various pharmacological effects. Biomed Res Int. 2014:569087.

14. Haranath, PSRK, Akhter, MH, Sharif, SI. Acetylcholine and choline in common spices. Phytotherapy Research. 1987;1:91-2.

Cite this article as: Vani GM, Ramesh $\mathrm{P}$, Radhika M, Devashankaraiah G, Haranath PSRK. Relaxant effects of aqueous cold extracts of Carum copticum on smooth muscle. Int J Basic Clin Pharmacol 2017;6:1638-42. 